\title{
Comparison of YD URiSCAN PluScope Urine Microscopic Analyzer and Sysmex UF-1000i Flow Cytometry Systems
}

Jae Won Jung, AeChin Oh, Yoon Hwan Chang, Jin Kyung Lee, and Young Jun Hong Department of Laboratory Medicine, Korea Cancer Center Hospital, Korea Institute of Radiological and Medical Sciences, Seoul, Korea

Corresponding author: Young Jun Hong Korea Cancer Center Hospital, Korea Institute of Radiological and Medical Sciences, 75 Nowonro, Nowon-gu, Seoul 01812,

Korea

Tel: +82-2-970-2492

Fax: +82-2-973-7143

E-mail: clinchem@kirams.re.kr

pISSN: 2384-2458

eISSN: 2288-7261
Background: Urinalysis is one of the most commonly performed tests in clinical laboratories. In this study, we compared YD URiSCAN PluScope (PluScope; YD Diagnostics Corp., Korea) and Sysmex UF-1000i (UF-1000i; Sysmex Corp., Japan) for urine microscopic sediment analysis.

Methods: A total of 404 fresh urine samples were collected and analyzed using PluScope, UF-1000i, and manual microscopy. Quantitative correlation analyses for red blood cells (RBCs), white blood cells (WBCs), epithelial cells (EC), and casts were performed using Spearman's correlation. We evaluated agreement among the three systems by using weighted Cohen's $\kappa$ and calculating concordance rates within one grade of difference for semiquantitative and qualitative parameters.

Results: There were moderate-high correlations between PluScope and UF-1000i for RBCs, WBCs, and ECs ( $r=0.542,0.714$, and 0.571 , respectively) but negligible correlation for casts $(r=0.186)$. There were moderate-high correlations between manual microscopy and automated devices for RBCs, WBCs, and ECs $(r=0.550-0.745)$ but negligible correlations for casts (PluScope: $r=0.247$; UF-1000i: $r=0.223$ ). The pairwise concordance rates within one grade difference among the three methods were good for RBCs, WBCs, and ECs (95.0\%-99.0\%, $\kappa=0.41-0.74)$. For casts, the concordance rate between PluScope and manual microscopy was fair $(96.8 \%, \kappa=0.25)$, but concordance rates between UF-1000i and manual microscopy and between the two automated devices were poor $(81.2 \%$ and $81.7 \%$; $\kappa=0.04$ and 0.06 , respectively).

Conclusions: The two automated urine sediment analyzers showed a moderate-high correlation and concordance rate. They showed good correlations and concordance rates for RBCs, WBCs, and ECs. However, manual microscopic examinations are still needed for reviewing and confirming the presence of pathologic particles in urine, such as casts and crystals.

(J Lab Med Qual Assur 2018;40:223-229)

Key Words: Automated urine sediment analyzer, Urinalysis, Urine sediment, URiSCAN PluScope, UF-1000i

Received September 24, 2018, Revision received October 19, 2018, Accepted October 24, 2018

\section{서론}

요검사는 임상영역에서 흔하게 시행하는 검사로, 검체의 채 집이 용이하고 비침습적인 검사며, 신장, 요로계 질환에서부터 내분비 및 대사성 질환 등의 전신성 질환에 이르기까지 다양한 질환에 대한 정보를 얻을 수 있는 장점이 있다[1].
요검사 중 수기법을 이용하는 요침사검사는 노동집약적이며 시간이 많이 소요되고, 검사자의 전문적인 판독능력이 필요하 다. 또한 검체 준비과정의 차이에 따라 검사결과가 달라질 수 있으며, 검사자 간 숙련도에 따라서도 판독에 차이가 있을 수 있다[2-5]. 이러한 수기법의 단점을 극복하기 위해 자동 요침 사 장비의 필요성이 대두되어 왔으며, 현재 여러 장비들이 대 


\section{Journal of LABORATORY MEDICINE and QUALITY ASSURANCE}

\section{Jae Won Jung et al C Comparison of URiSCAN PluScope and UF-1000i}

다수의 검사실에 도입되어 사용 중이다.

자동 요침사 장비의 검사방법은 크게 유세포분석(flow cytometry)을 이용한 방법과 디지털 이미지를 촬영하여 분 석하는 방법으로 나눌 수 있으며, 지금까지 여러 장비들에 대 한 검사수행능 및 장비 간 상관성이 보고되고 있다[6-14]. YD URiSCAN PluScope (PluScope; YD Diagnostics Corp., Yongin, Korea)는 국산 장비로는 최초로 개발된 이미지 기 반 자동 요침사 장비로서 현재까지 PluScope에 대한 장비평 가는 거의 없었다. 본 연구에서는 환자의 소변 검체를 대상으 로 이미지 촬영 및 분석기술을 이용하는 PluScope와 유세포분 석 기술을 이용하는 Sysmex UF-1000i (UF-1000i; Sysmex Corp., Kobe, Japan)의 검사수행능을 비교하였고, 각각 수기 법과의 상관성에 대해서도 분석하였다.

\section{재료 및 방법}

\section{1. 대상 검체}

원자력병원 진단검사의학과에 검사가 의뢰된 검체 중 잔여 소변 검체 404개를 무작위로 선정하였다. 연구대상 검체는 채 취 후 1 시간 이내의 신선한 검체이며, 잔여 검체의 양이 평가 를 수행하는 데 필요한 $20 \mathrm{~mL}$ 이상 남아있는 것들을 기준으로 하였다. 본 연구는 한국원자력의학원 임상연구심의위원회의 심의를 통과하였다(IRB approval no., 2018-08-010-002).

\section{2. 검사방법}

\section{1) YD URISCAN PluScope}

PluScope 장비는 원심분리하지 않은 소변 검체 $2.5 \mathrm{~mL}$ 를 이용하여 4 개의 counting chamber system에 검체를 주입 하여 빠른 시간 안에 효율적으로 디지털 이미지를 촬영함으 로써 요침사의 계수 및 형태학적 분석을 시행하는 자동화 장 비다. 적혈구(red blood cell), 백혈구(white blood cell), 백 혈구 응괴(WBC clumping), 상피세포(epithelial cell), 초 자원주(hyaline cast), 결정(crystal), 진균(fungus), 미분류 (unclassified), 소원형세포(small round cell)의 9개 분석대상 에 대해 정량적으로 측정하였으며, 박테리아(bacteria)와 점액 질(mucus)에 대해서는 반정량적으로 결과를 측정하였다.

\section{2) Sysmex UF-1000i}

UF-1000i 장비는 유세포분석 기술을 기반으로 하며, 두 가 지의 형광염색과 $635 \mathrm{~nm}$ 의 반도체 레이저를 이용하여 검체를 분석한다. 원심분리하지 않은 검체 $4 \mathrm{~mL}$ 를 사용하며, 요침사
의 구성성분에 따라 전반산란광, 측방산란광, 측방산란형광이 다르게 측정된 정보를 바탕으로 각 검사항목별 결과를 얻을 수 있다. 적혈구, 백혈구, 상피세포, 원주, 박테리아의 5 개 분석대 상에 대해 정량적으로 측정하였으며, flag로 확인되는 결정, 진 균, 병적 원주(pathologic cast), 점액질, 정자(spermatozoa), 소원형세포에 대해서는 count/ $\mu \mathrm{L}$ 로 결과를 기록하였다.

\section{3) 수기법}

수기 요침사검사는 Clinical and Laboratory Standards Institute (CLSI)에서 제시한 지침에 따라 시행하였다 $\lceil 15,16\rceil$. 현미경 계수는 표준화된 KOVA cell chamber system을 이용하였다. $12 \mathrm{~mL}$ 의 소변 검체를 $1,500 \mathrm{rpm}$ 에서 $(\times 400 \mathrm{~g}) 5$ 분간 원심분리하여 상층액은 버리고 $1 \mathrm{~mL}$ 를 남겨 재부유한 후 $6.6 \mu \mathrm{L}$ 를 slide에 떨어뜨리고 염색하지 않은 상태 에서 현미경으로 관찰하였다. 현미경 경검은 고배율(400배)에 서 10시야 이상 관찰하여 백혈구, 적혈구, 상피세포의 개수를 계수하고 각각의 평균치를 count/high-power field (HPF)로 기록하였고, 저배율(100배)에서 10시야 이상 관찰하여 박테리 아, 진균, 결정, 원주, 점액질에 대한 각각의 평균치를 count/ low-power field $(\mathrm{LPF})$ 로 기록하였다.

\section{3. 평가방법}

\section{1) 정밀도 및 carryover 평가}

정밀도를 평가하기 위해 2 가지 농도의 pooled urine 검체 에 대해 PluScope와 UF-1000i에서 하루, 5 회 반복 측정하여 각각 변이계수를 구하였다. Carryover 평가를 위해 고농도 검체 4개 $(\mathrm{H} 1, \mathrm{H} 2, \mathrm{H} 3, \mathrm{H} 4)$ 와 저농도 검체 4개(L1, L2, L3, L4)를 PluScope와 UF- $1000 \mathrm{i}$ 각 장비별로 연속 측정한 결과 로 다음의 식을 이용하여 계산하였다: carryover $\%=\{\mathrm{L} 1-$ $(\mathrm{L} 3+\mathrm{L} 4) / 2\} /\{(\mathrm{H} 2+\mathrm{H} 3) / 2-(\mathrm{L} 3+\mathrm{L} 4) / 2\} \times 100$.

\section{2) 단위의 통일}

두 자동화 장비를 통해 수집된 검사결과들의 단위(count) $\mu \mathrm{L})$ 를 수기법과의 비교를 위해 종목별로 통일하였다. 적혈구, 백혈구, 상피세포는 count/ $\mathrm{HPF}$ 로, 원주, 박테리아, 진균, 결 정, 점액질에 대해서는 count $/ \mathrm{LPF}$ 로 단위를 변환하였다. 단위 간 변환에 사용된 공식은 다음과 같다: count $\times 10^{6} / \mathrm{L}=(10$ 시 야 계수한 세포의 총합 $) \times($ 원심분리 후 남은 부피, $1 \mathrm{~mL}) /($ 관 찰한 10 개 시야의 부피, $0.1111 \mu \mathrm{L}) \times($ 검체의 부피, $12 \mathrm{~mL}$ ) 〔17]. 


\section{Journal of LABORATORY MEDICINE and QUALITY ASSURANCE}

\section{Jae Won Jung et al • Comparison of URiSCAN PluScope and UF-1000i}

\section{3) 정량적 상관성 비교}

PluScope와 UF-1000i 장비 간, 그리고 자동화 장비와 수기 법 간의 정량적 비교를 위한 검사종목으로 적혈구, 백혈구, 상 피세포, 원주를 선정하였다. 총 404개의 잔여 소변 검체를 대 상으로 분석하였다. 통계프로그램으로 IBM SPSS ver. 23.0 (IBM Corp., Armonk, NY, USA) 소프트웨어를 사용하였고, 데이터의 정규성 검정을 위해 Kolmogorov-Smirnov test를 시행 한 결과 모든 분석데이터는 정규분포를 이루지 않았다. 비모수 적 데이터에 대한 상관성 분석을 위해 Spearman's correlation 분석을 사용하였으며, 상관계수(correlation coefficient, $r$ ) 값 이 0.9 이상이면 매우 높은(very high) 상관성을, 0.7-0.9일 경 우 높은(high) 상관성을, 0.5-0.7일 경우 중등도(moderate)의 상관성, 0.3-0.5의 경우 낮은(low) 상관성, 0.0-0.3을 매우 낮 은(무시할 수준, negligible) 상관성을 보이는 것으로 판정하였 다[18]. 통계분석결과는 $P$ 값이 0.05 미만일 때 유의한 것으로 간주하였다.

\section{4) 반정량적 또는 정성적 일치도 비교}

PluScope와 UF-1000i 장비 간, 그리고 자동화 장비와 수
기법 간 서로 비교 가능한 8 개의 검사종목에 대한 분석결과 를 반정량적 또는 정성적으로 분류하여 Table 1과 같이 등급 (grade)을 나누었다. 하나의 장비에서만 측정되는 검사항목 은 분석에서 제외되었다. 통계학적 비교방법으로 weighted Cohen's kappa 분석을 이용하여 총 404개의 잔여 소변 검체 에 대해 kappa 계수(к)와 일치도(concordance rate)를 계산 하였으며, 적혈구와 백혈구, 상피세포, 원주, 박테리아에 대해 서는 1 등급 차이 내의 일치도를 구하였다. 일치의 정도는 $\kappa$ 값 이 0.81-1.00일 때 매우 좋은(very good) 일치, 0.61-0.80일 때 좋은(good) 일치, 0.41-0.60일 때 중등도(moderate)의 일치, $0.21-0.40$ 일 때 약간의(fair) 일치, 0.20 미만일 때 좋지 않은 (poor) 일치를 보이는 것으로 해석하였고[19], $P$ 값이 0.05 미 만의 경우 유의한 것으로 간주하였다.

\section{결과}

\section{1. 정밀도 및 carryover 평가}

정밀도 평가결과 PluScope의 적혈구에 대한 검사 내 변 이계수는 적혈구에서 $2.8 \%, 2.3 \%$ (각각 고농도, 저농도)였

Table 1. Semi-quantitative and qualitative range classification of urine sediment results of three different examination methods

\begin{tabular}{|c|c|c|c|c|c|c|}
\hline \multirow{2}{*}{ Variable } & \multicolumn{6}{|c|}{ Grade } \\
\hline & 1 & 2 & 3 & 4 & 5 & 6 \\
\hline Red blood cell (counts/HPF) & $<1$ & $1-4$ & $5-9$ & $10-29$ & $30-99$ & $\geq 100$ \\
\hline White blood cell (counts/HPF) & $<1$ & $1-4$ & $5-9$ & $10-29$ & $30-99$ & $\geq 100$ \\
\hline Epithelial cell (counts/HPF) & $<1$ & $1-4$ & $5-9$ & $10-29$ & $30-99$ & $\geq 100$ \\
\hline Casts (counts/LPF) & $<1$ & $1-2$ & $3-5$ & $6-10$ & $11-20$ & $\geq 20$ \\
\hline Bacteria & Rare & A few & Some & Many & & \\
\hline Fungus & $(-)$ & $(+)$ & & & & \\
\hline Crystal & $(-)$ & $(+)$ & & & & \\
\hline Mucus & $(-)$ & $(+)$ & & & & \\
\hline
\end{tabular}

Abbreviations: HPF, high-power field; LPF, low-power field.

Table 2. Within-run imprecision of two automated urine sediment analyzers ( $\mathrm{N}=404)$

\begin{tabular}{|c|c|c|c|c|}
\hline \multirow{2}{*}{ Variable } & \multicolumn{2}{|c|}{ Level 1 (low) } & \multicolumn{2}{|c|}{ Level 2 (high) } \\
\hline & Mean \pm SD (counts/ $\mu \mathrm{L})$ & $\mathrm{CV}(\%)$ & Mean \pm SD (counts $/ \mu \mathrm{L})$ & $\mathrm{CV}(\%)$ \\
\hline \multicolumn{5}{|l|}{ URiSCAN PluScope } \\
\hline $\mathrm{RBC}$ & $276.00 \pm 6.28$ & 2.3 & $377.20 \pm 10.55$ & 2.8 \\
\hline WBC & $40.40 \pm 1.14$ & 2.8 & $659.60 \pm 46.10$ & 7.0 \\
\hline \multicolumn{5}{|l|}{ UF-1000i } \\
\hline $\mathrm{RBC}$ & $493.52 \pm 7.24$ & 1.5 & $622.42 \pm 17.14$ & 2.8 \\
\hline WBC & $56.14 \pm 1.88$ & 3.3 & $1074.00 \pm 15.44$ & 1.4 \\
\hline
\end{tabular}

Abbreviations: SD, standard deviation; CV, coefficient of variation; RBC, red blood cell; WBC, white blood cell. 


\section{Journal of LABORATORY MEDICINE and QUALITY ASSURANCE}

\section{Jae Won Jung et al • Comparison of URiSCAN PluScope and UF-1000i}

고, 백혈구에 대해 $7.0 \%, 2.8 \%$ 였다. UF- $1000 \mathrm{i}$ 의 적혈구에 대한 검사 내 변이계수는 $2.8 \%, 1.5 \%$ 였고, 백혈구에 대해 $1.4 \%, 3.3 \%$ 였다(Table 2). Carryover 평가결과 PluScope의 carryover는 적혈구와 백혈구 모두에서 $0.0 \%$ 였고, UF- $1000 \mathrm{i}$ 의 carryover는 적혈구와 백혈구에 대해 각각 $0.1 \%$ 와 $0.2 \%$ 였 다.

\section{2. 상관성 분석}

Spearman correlation을 이용하여 분석한 상관성 결과는 Table 3 와 같다. PluScope와 UF-1000i 두 장비 간 상관성 분 석결과 백혈구에 대해서는 $r$ 값이 0.714 로 높은 상관관계를, 적 혈구와 상피세포에 대해서는 각각 $r$ 값이 0.542 와 0.571 로 중 등도의 상관관계를 보였으며, 원주에 대해서는 $r$ 값은 0.186 으 로 매우 낮은 상관관계를 보였다.

수기법과 각 자동화 장비 간 상관성 분석결과 적혈구에 대 해서는 PluScope와 UF-1000i의 $r$ 값은 각각 0.586과 0.644로 중등도의 상관관계를 보였고, 백혈구에 대해서는 PluScope 에서 중등도 $(r=0.599)$ 의 상관관계, $\mathrm{UF}-1000 \mathrm{i}$ 에서는 높은 $(r=0.745)$ 상관관계를 보였다. 상피세포에서 PluScope와 $\mathrm{UF}-1000 \mathrm{i}$ 의 $r$ 값은 각각 0.585 와 0.550 으로 중등도의 상관관 계를 보였으며, 원주에 대한 PluScope와 UF-1000i의 $r$ 값은
각각 $r=0.247$ 와 0.223 으로 매우 낮은 상관관계를 보였다.

\section{3. 분석종목별 일치도 비교}

두 장비 간, 그리고 장비와 수기법 간의 일치도 분석과 weighted Cohen's kappa 분석결과는 Table 4와 같다. 적혈구 에 대한 일치도 분석결과 PluScope 장비와 수기법 간의 1 등급 내 일치도는 98.5\% (398/404)였고( $\kappa=0.65), 6$ 개의 검체에서 2 등급 이상의 불일치를 보였다. UF- $1000 \mathrm{i}$ 장비와 수기법 간 의 1 등급 내 일치도는 $96.3 \%$ (389/404)였으며 $(\kappa=0.50), 15$ 개의 검체에서 수기법에 비하여 2등급 이상 높게 측정되었다. PluScope와 UF-1000i 두 장비 간 1등급 내 일치도는 $95.0 \%$ (384/404)였고 $(\kappa=0.51), 2$ 등급 이상 차이를 보인 20 개의 검 체 중 16 개에서 UF- 1000 i의 검사결과가 PluScope의 결과보 다 높게 측정되었다.

백혈구에 대한 일치도 분석결과 PluScope 장비와 수기법 간 일치도는 97.0\% (392/404)였으며( $\kappa=0.69), 2$ 등급 이상 차이 를 보인 12 개의 검체 중 10 개에서 수기법 결과가 PluScope의 검사결과보다 높게 측정되었다. UF-1000i와 수기법 간 일치 도는 98.0\% (396/404)였고( $\kappa=0.74), 2$ 등급 이상 차이를 보 인 8개의 검체 중 7 개에서 수기법보다 높게 측정되었다. 두 자 동화 장비 간 일치도는 $95.5 \%$ 였고 $(\kappa=0.64), \mathrm{UF}-1000 \mathrm{i}$ 의 검

Table 3. Spearman correlation analysis of pairwise results among URiSCAN PluScope, UF-1000i, and manual microscopy (N=404)

\begin{tabular}{|c|c|c|c|c|c|c|}
\hline \multirow[t]{2}{*}{ Variable } & \multicolumn{2}{|c|}{ URiSCAN PluScope vs. UF-1000i } & \multicolumn{2}{|c|}{$\begin{array}{l}\text { URiSCAN PluScope vs. manual } \\
\text { microscopy }\end{array}$} & \multicolumn{2}{|c|}{ UF-1000i vs. manual microscopy } \\
\hline & $r$ & $P$-value & $r$ & $P$-value & $r$ & $P$-value \\
\hline Red blood cell & 0.542 & $<0.001$ & 0.586 & $<0.001$ & 0.644 & $<0.001$ \\
\hline White blood cell & 0.714 & $<0.001$ & 0.599 & $<0.001$ & 0.745 & $<0.001$ \\
\hline Epithelial cell & 0.571 & $<0.001$ & 0.585 & $<0.001$ & 0.550 & $<0.001$ \\
\hline Casts & 0.186 & $<0.001$ & 0.247 & $<0.001$ & 0.223 & $<0.001$ \\
\hline
\end{tabular}

Abbreviation: $r$, Spearman correlation of coefficient.

Table 4. Pairwise concordance rates within one grade difference and kappa coefficients ( $\kappa)$ for comparison among the three methods (N=404)

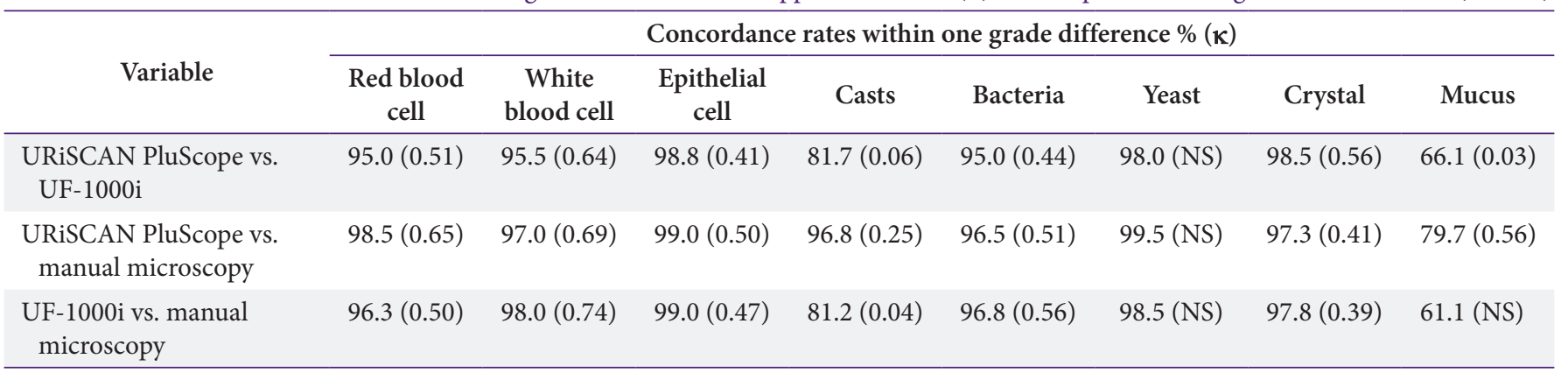

Abbreviations: $\kappa$, kappa coefficient; NS, not significant.

$P>0.05$. 


\section{Journal of LABORATORY MEDICINE and QUALITY ASSURANCE}

\section{Jae Won Jung et al • Comparison of URiSCAN PluScope and UF-1000i}

사결과가 PluScope보다 높게 측정되는 경향이 관찰되었다.

상피세포에 대한 일치도 분석결과 PluScope와 수기법 간, $\mathrm{UF}-1000 \mathrm{i}$ 와 수기법 간 및 PluScope와 UF- $1000 \mathrm{i}$ 간의 일 치도는 각각 99.0\% (400/404), 99.0\% (400/404), 98.8\% (399/404)였으나(각각 $\kappa=0.50,0.47,0.41)$, 대부분의 검체 결과들이 10-29/HPF 미만으로 grade 1, 2, 3 내의 편향적인 분포를 보이고 있었다.

원주에 대한 일치도 분석결과 PluScope와 수기법 간 일 치도가 $96.8 \%$ (391/404)였으며 $(\kappa=0.25), 2$ 등급 이상 차이 를 보인 13 개의 검체에서 PluScope의 검사결과가 수기법보 다 낮게 측정되었다. UF-1000i와 수기법 간 일치도는 $81.2 \%$ (328/404)였고 $(\kappa=0.04), 2$ 등급 이상의 차이를 보인 76 개의 검체 중 71 개에서 UF-1000i의 검사결과가 수기법보다 높게 측정되었다. 두 자동화 장비 간 일치도는 81.7\% (330/404)였 으며 $(\kappa=0.06), \mathrm{UF}-1000 \mathrm{i}$ 의 검사결과가 PluScope에 비해 높 게 측정되었다.

박테리아에 대한 일치도 분석결과 장비 간 일치도는 95.0\% (384/404)였고 $(\kappa=0.44)$, 장비와 수기법 간 일치도 는 PluScope와 UF-1000i 각각 96.5\% (390/404)와 96.8\% (391/404)였다(각각 $\kappa=0.51,0.56)$. 진균에 대한 일치도 분 석에서의 장비 간 일치도는 98.0\% (396/404), 장비와 수기법 간 일치도는 PluScope와 UF-1000i 각각 99.5\% (402/404), 98.5\% (398/404)였으나, kappa 분석에서는 к값은 모두 0으 로 나타났고 통계적으로도 유의하지 않았다 $(P>0.05)$.

결정에 대한 일치도 분석에서의 장비 간 일치도는 $98.5 \%$ (398/404)였고 $(\kappa=0.56)$, 장비와 수기법 간 일치도 는 PluScope와 UF-1000i 각각 97.3\% (393/404), 97.8\% (395/404)였다(각각 $\kappa=0.41,0.39)$. 점액질에 대한 일치도 분석결과 장비 간 일치도는 $66.1 \%(267 / 404)$ 였고 $(\kappa=0.03)$, 장비와 수기법 간 일치도는 PluScope와 수기법 간 일치도는 79.7\% (322/404)였으며 $(\kappa=0.56), \mathrm{UF}-1000 i$ 와 수기법 간 일 치도는 $61.1 \%$ (247/404)였다( $\kappa=0.01, P>0.05$ 로 통계적으 로 유의하지 않음).

\section{고찰}

수기 요침사검사는 검사실에 따라 최초 검체량, 원심분리의 정도, 검체 농축 정도, 슬라이드에 떨어뜨리는 검체량, 관찰 및 기록방법 등에 따라 검사결과가 달라질 수 있다. 요침사 수기 법에 대한 국제적인 가이드라인도 여러 개가 존재하여 검사방 법에 차이가 있고[15,16,20,21], 여러 검사실마다 고유의 프로 토콜에 따라 요침사검사를 진행하여 방법과 해석에 차이가 있
을 수 있기 때문에 표준화된 외부정도관리에 어려움이 있다[25]. 이러한 검사방법의 다양성을 줄이고, 검사소요시간과 번거 로운 수작업을 줄여 효율적인 검사수행을 할 수 있는 장점이 있어 자동 요침사 장비가 점점 많은 임상검사실에 도입되고 있 다.

본 연구에서는 최초의 국산 이미지 기반 장비인 PluScope 와 유세포분석 기반의 UF-1000i 장비에 대하여 정밀도와 carryover, 장비 간 및 수기법과의 상관성과 일치도에 대해 분석하였다. 적혈구, 백혈구, 상피세포에 대한 상관성 분석 에서는 PluScope와 UF-1000i 간, 그리고 자동화 장비와 수 기법 간에 모두 중등도 이상의 상관성을 보였지만 UF-1000i 에서 적혈구, 백혈구가 PluScope에 비해 다소 높게 측정되 는 경향을 보였다. 이에 대한 원인은 명확하지 않지만, 아마 도 검사방법 간 측정원리의 차이 때문에 발생한 것으로 생 각된다. PluScope와 수기법검사는 공통적으로 현미경적 형 태(morphology)를 바탕으로 요침사를 분류하는 반면, UF$1000 i$ 의 경우 유세포분석을 이용하여 요침사 입자를 분류하 며, 흔하지는 않지만 유사한 크기와 세포복잡도를 가진 입자를 적혈구 또는 백혈구로 잘못 인식할 수 있기 때문이다. Chien 등[6]의 유세포분석 장비 UF-100과 이미지분석 장비 iQ-200 의 비교연구에서는 UF-100의 적혈구 및 백혈구 측정결과가 iQ-200에 비해 조금 높았고, Lee 등[10]의 연구에서 유세포분 석 장비 UF-1000i와 이미지분석 장비 cobas u 701를 비교한 결과 적혈구 및 백혈구 측정에서 UF-1000i가 cobas u 701보 다 약간 높은 경향을 보였으나 그 이유는 명확하지 않았다.

원주에서는 모두 낮은 상관성을 보였고 일치도 비교에서 도 원주에서 낮은 일치를 보였다. 원주에서 관찰되는 낮은 상 관성, 나쁜 일치도의 원인으로 먼저 장비 간 원주 측정의 원 리와 계수방법의 차이에 의한 것을 생각해 볼 수 있다. UF$1000 i$ 는 원주에 대해서는 정량적 측정을 하고 병적 원주에 대 해서는 정해진 cut-off에 따라 flag를 띄워 존재 유무를 확인하 는 반면, PluScope는 주로 초자원주의 형태를 인식하여 측정 하기 때문에 계수대상의 차이로 인해 낮은 일치도와 상관성을 보였을 가능성이 있다. 본 분석에서는 UF-1000i의 원주와 병 적 원주의 측정결과를 구분하지 않고 합쳐서 분석하였고, UF1000i의 병적 원주에 대한 flag의 cut-off가 상대적으로 낮게 설정되어 전체 원주에 대한 계수가 PluScope와 수기법의 결과 보다 상대적으로 더 높게 측정되었을 수 있다고 생각된다. 다 른 원인으로는 수기 요침사검사의 검체 준비과정 중 하나인 원 심분리과정에서 불안정한 원주가 파괴되어 수기법의 결과에 서 상대적으로 낮게 계수되었을 수도 있다. 또다른 원인으로는 PluScope와 수기법 장비 모두 현미경 관찰 또는 디지털 이미 


\section{Journal of LABORATORY MEDICINE and QUALITY ASSURANCE}

Jae Won Jung et al • Comparison of URiSCAN PluScope and UF-1000i

지 분석으로 형태학적 구분을 통해 계수하는데, 초자원주의 경 우 광학 현미경에서 투명하게 관찰되므로 계수가 되지 않았을 수 있다.

일치도 분석결과 박테리아, 결정에 대해서는 양호한 일치를 보였으나 진균과 점액질에 대해서는 일치도가 매우 좋지 않았 다. 진균의 경우 일치도는 높았지만 Cohen's kappa 분석에서 통계적 유의성이 없었는데, 이는 분석 검체의 대다수가 진균에 대해 음성 검체들이었고, kappa 분석에서는 우연에 의한 일치 도를 배제하여 평가하기 때문일 것으로 생각된다.

PluScope 장비에서 '미분류(unclassified)'로 나온 결과와 UF-1000i에서 flag가 표시된 결과에 대해서는 이미지 재확인 또는 수기법을 통한 검토(review)가 필요하다. 검토가 필요한 경우 UF-1000i 장비에서는 원심분리, 슬라이드 제작 등의 번 거로운 검체 준비과정이 있어야 하나, PluScope의 경우 미분 류로 분류된 사진이 디지털 이미지로 촬영되어 저장되기 때문 에 불필요한 검체 준비과정을 피하고 촬영한 이미지를 확인함 으로써 직접 검토가 가능하다는 장점이 있다.

원주, 결정 등 드물게 관찰되는 병적인 소견들이 자동화 장 비에서 확인되지 않을 수 있기 때문에 검토 및 확인검사로서 수기로 시행하는 요경검검사가 반드시 필요하다고 여러 논문 에서 언급하였으며 [6,8-12], 일부 연구에서는 검토율(review rate)을 요화학검사와 요침사검사와의 비교(예를 들어, 적 혈구와 잠혈반응, 백혈구와 leukocyte esterase, 박테리아와 nitrite 등)를 통해 줄일 수 있다고 주장하였다 $[8,10,11,22]$. 임 상검사실에서 환자의 요검사결과를 자동화 장비로 보고할 때, 병적인 상태를 반영하는 원주나 결정 등의 경우 '미분류'로 보 고되는 항목들의 유무를 주의 깊게 확인하고 검토하여야 한다. 이런 이유들로 인해 수기법을 통한 현미경 판독은 현재로서는 아직 자동화 기기가 완전히 대체할 수 없다.

본 연구의 제한점은 다음과 같다. 첫째, 자동화 장비의 정밀 도 평가에서 상품화된 정도관리물질 대신 pooled urine 검체 를 사용하였다. 그 이유는 두 장비 간 비교평가 연구를 위해서 는 공통물질을 통해 장비의 성능평가를 하고자 하는 것이 본 연구의 목적인데, 연구 준비과정에서 각 장비에서 별도로 사용 가능한 정도관리물질은 구할 수 있었으나 공통으로 사용 가능 한 정도관리물질은 구할 수가 없었기 때문이다. 이에 저자들은 정밀도 평가를 위한 정도관리물질로서 pooled urine을 이용하 였으며, CLSI에서 제시한 지침[23]에 맞게 정밀도 평가를 수 행하려 했으나 요 검체의 특성상 검체의 불안정성으로 5 일간 분석을 하지 못하고 부득이하게 하루 5 회 측정한 결과로 변이 계수를 산출하여 정밀도 평가에 부족한 부분이 있었다. 향후 두 장비에 공통으로 사용 가능한 정도관리물질을 이용하여 정
밀도를 평가하면 더 나은 결과를 얻을 수 있을 것으로 기대된 다. 두번째로, 상피세포 및 진균, 결정에 대한 일치도 비교에서 검사결과가 대부분 음성 또는 낮은 결과를 보여, 분포가 편중 되고 고농도에서의 일치도는 평가되지 못하였다. 향후 병리적 변화가 있는 비뇨기계 및 신장내과 환자의 검체를 추가하여 분 석한다면 더 좋은 비교분석을 할 수 있을 것이다.

\section{감사의 글}

이 연구는 과학기술정보통신부 한국원자력의학원 연구운영 비지원사업의 지원을 받아 수행하였다(50544-2018).

\section{REFERENCES}

1. Riley RS, McPherson RA. Basic examination of urine. In: McPherson RA, Pincus MR, editors. Henry's clinical diagnosis and management by laboratory methods. 23th ed. St. Louis (MO): Elsevier, 2017:442-80.

2. Delanghe JR, Speeckaert MM. Preanalytics in urinalysis. Clin Biochem 2016;49:1346-50.

3. Wald R, Bell CM, Nisenbaum R, Perrone S, Liangos O, Laupacis A, et al. Interobserver reliability of urine sediment interpretation. Clin J Am Soc Nephrol 2009;4:56771.

4. Broeren MA, Bahceci S, Vader HL, Arents NL. Screening for urinary tract infection with the Sysmex UF-1000i urine flow cytometer. J Clin Microbiol 2011;49:1025-9.

5. Lee AJ, Park CG, Bae YC, Jeon CH. Quality improvement of urinalysis results based on automatic sediment urinalysis and urine strip results. J Lab Med Qual Assur 2017;39: 154-61.

6. Chien TI, Kao JT, Liu HL, Lin PC, Hong JS, Hsieh HP, et al. Urine sediment examination: a comparison of automated urinalysis systems and manual microscopy. Clin Chim Acta 2007;384:28-34.

7. Zaman Z, Fogazzi GB, Garigali G, Croci MD, Bayer G, Kranicz T. Urine sediment analysis: analytical and diagnostic performance of sediMAX - a new automated microscopy image-based urine sediment analyser. Clin Chim Acta 2010;411:147-54.

8. Jiang T, Chen P, Ouyang J, Zhang S, Cai D. Urine particles analysis: performance evaluation of Sysmex UF-1000i 


\section{Journal of LABORATORY MEDICINE and QUALITY ASSURANCE}

Jae Won Jung et al • Comparison of URiSCAN PluScope and UF-1000i

and comparison among urine flow cytometer, dipstick, and visual microscopic examination. Scand J Clin Lab Invest 2011;71:30-7.

9. Yuksel H, Kilic E, Ekinci A, Evliyaoglu O. Comparison of fully automated urine sediment analyzers H800-FUS100 and LabUMat-UriSed with manual microscopy. J Clin Lab Anal 2013;27:312-6.

10. Lee W, Ha JS, Ryoo NH. Comparison of the automated cobas u 701 urine microscopy and UF-1000i flow cytometry systems and manual microscopy in the examination of urine sediments. J Clin Lab Anal 2016;30:663-71.

11. Wesarachkitti B, Khejonnit V, Pratumvinit B, Reesukumal K, Meepanya S, Pattanavin C, et al. Performance Evaluation and comparison of the fully automated urinalysis analyzers UX-2000 and Cobas 6500. Lab Med 2016;47:12433.

12. Bakan E, Ozturk N, Baygutalp NK, Polat E, Akpinar K, Dorman E, et al. Comparison of Cobas 6500 and Iris IQ200 fully-automated urine analyzers to manual urine microscopy. Biochem Med (Zagreb) 2016;26:365-75.

13. Bogaert L, Peeters B, Billen J. Evaluation of a new automated microscopy urine sediment analyser: sediMAX conTRUST. Acta Clin Belg 2017;72:91-4.

14. Ince FD, Ellidag HY, Koseoglu M, Simsek N, Yalcin H, Zengin MO. The comparison of automated urine analyzers with manual microscopic examination for urinalysis automated urine analyzers and manual urinalysis. Pract Lab Med 2016;5:14-20.

15. Clinical and Laboratory Standards Institute. Urinalysis: approved guideline: GP16-A3. 3rd ed. Wayne (PA): Clinical and Laboratory Standards Institute, 2009.
16. Clinical and Laboratory Standards Institute. Physician and nonphysician provider-performed microscopy testing: approved guideline: POCT10-A2. 2nd ed. Wayne (PA): Clinical and Laboratory Standards Institute, 2011.

17. Ottiger C, Huber AR. Quantitative urine particle analysis: integrative approach for the optimal combination of automation with UF-100 and microscopic review with KOVA cell chamber. Clin Chem 2003;49:617-23.

18. Mukaka MM. Statistics corner: a guide to appropriate use of correlation coefficient in medical research. Malawi Med J 2012;24:69-71.

19. Landis JR, Koch GG. The measurement of observer agreement for categorical data. Biometrics 1977;33:15974.

20. European Confederation of Laboratory Medicine. European urinalysis guidelines. Scand J Clin Lab Invest Suppl 2000;231:1-86.

21. Japanese Association of Medical Technologists. Aims of the guidelines on urinary sediment examination procedures proposed by the Japanese committee for clinical laboratory standards (JCCLS). Jpn J Med Technol 2017; 66:9-17.

22. Khejonnit V, Pratumvinit B, Reesukumal K, Meepanya S, Pattanavin C, Wongkrajang P. Optimal criteria for microscopic review of urinalysis following use of automated urine analyzer. Clin Chim Acta 2015;439:1-4.

23. Clinical and Laboratory Standards Institute. User verification of precision and estimation of bias: approved guideline: EP15-A3. 3rd ed. Wayne (PA): Clinical and Laboratory Standards Institute, 2014. 